\title{
Effect of Leadership, Employee Engagement, and Self Learning on Effectiveness of Employee's Work
}

\author{
Paima Erianto Hasibuan ${ }^{1}$, Maruf Akbar ${ }^{2}$, Thomas Suyanto ${ }^{3}$ \\ Universitas Negeri Jakarta \\ Rawamangun Muka-Rawamangun Street East Jakarta, 13220
}

\begin{abstract}
Purpose - The aim of this article is to analysis, an organizational performance through process systematically to improve organizational performance through improving the performance of individuals and teams.

Design / methodology / approach - This study, used survey method with quantitative approach, the instrument measuring instrument in the form of a questionnaire. This study population as many as 133 employees. Saturated sampling used in this study. The test instrument Carried out on 30 employees. Analysis was done by using descriptive and inferential statistics.

Findings - The results show that Leadership has positive effect on Employee Effectiveness, Employee Engagement positively effect on Employee Effectiveness, Positive effect on the Independent Learning Employee Effectiveness, Leadership has positive effect on employee engagement, Leadership has positively effect on Self-egulated Learning and Employee Engagement positively affects Self-Learning.

Practical implications - This study highlights the importance of providing support to Leadership, Employee Engagement, Self Learning and the effect on Effectiveness of Employee's Work.
\end{abstract}

Keywords: Leadership, Engagement, Self-Learning, Effectiveness JEL: M0, M5

\section{Background}

Ideally, banks which apply performance management will get increased profitability in a sustainable manner, because the perspective is built not only short term but also long-term. This is contrary to the facts that occurred, such as in Indonesia with the closure of banks and bail out the US government conducted against Citigroup and several other banks in the era of 2008-2009.

The fact is interesting for researchers to observe what happens to the Bank Tabungan Negara (Persero) Tbk, which has implemented a performance management contained in Directors Circular Letter No. 39 / DIR / CMO / 2012 on Standard Operating Procedure (SOP) Strategy and Performance Management System Bank Tabungan Negara (Persero), Tbk, or BTN Strategic and Performance Management System (BTN STROMS) came into effect since September 13, 2012.

In the preamble to the circular revealed that performance management is the management of the Bank Tabungan Negara (Persero) Tbk should be organized through the process and measurable results that refer to the selected strategic framework to achieve the vision and mission of the organization and win the competition. This requires the existence of a regulation governing the preparation and management guidelines Strategy and Performance Management System BTN or BTN Strategic and Performance Management System (BTN STORMS).

What is the impact of the implementation of the performance Stroms BTN, can be seen in the summary of the performance of BTN Bank in graph 1.1. Interesting look at the growth of assets, loans and fund the Bank Tabungan Negara (Persero) Tbk also called BTN, the period from 2012 to 2015, assets, loans and deposits increased proportionally, seen by the graph continue to rise. But on the profit side, things that happen are not linear with the growth of its business scale fluctuations in earnings decline in 2014. 
Chart 1.1: The performance of the Bank Tabungan Negara (Persero) Tbk Year 2012-2015.
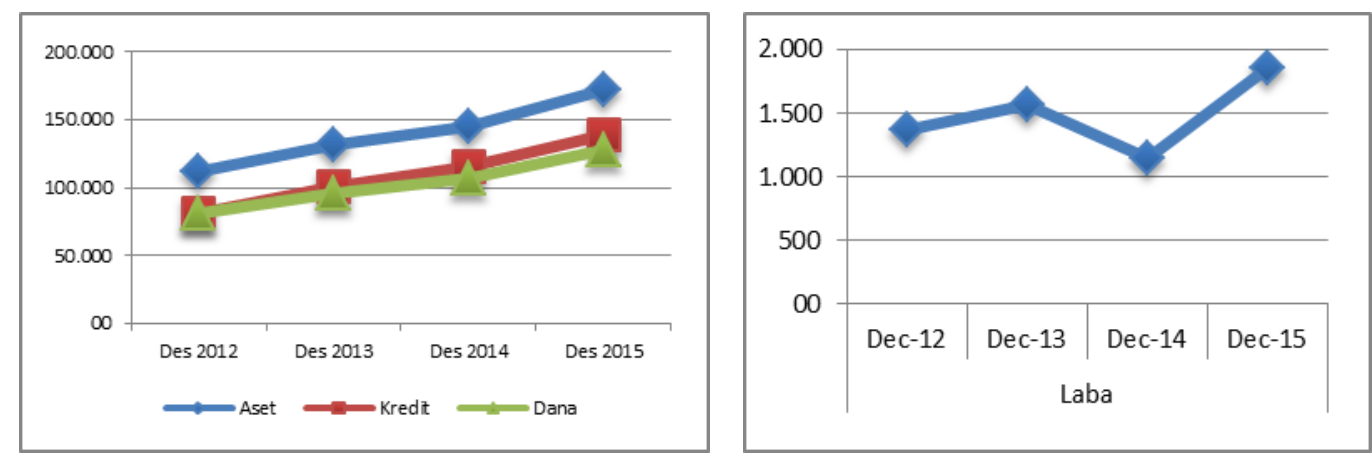

Source: Annual Report Bank Tabungan Negara

These facts make the researchers are interested to observe your what happens in the Bank Tabungan Negara (Persero) Tbk BTN achieved a performance that isn't aligned with Armstrong's opinion (2009), that performance management aims to improve organizational performance through process systematically to improve organizational performance through improving the performance of individuals and teams. This study interested to review this situation further, particularly subject to the Bank Tabungan Negara (Persero) Tbk, published in July 2014 out of the special supervision of the Financial Services Authority, This shows that the bank's previous red plate into the patient of the FSA.

Graph 1.1 and publication in July 2014 the Bank Tabungan Negara (Persero) Tbk out of the special supervision of the FSA strengthens the case investigators that the effectiveness of employees at Bank BTN has not been implemented well, because if employees are effectively it will have an impact on the performance of an organization that is growing well and sustainable.

Human resource management as well as the study results of the Shikha, Nankervis and Gamage (2010) in line with what was stated Armstrong, that in order to improve organizational performance requires the development of individual and team performance. This means that to get a better understanding and performance management frameworks to shortly achieve agreed goals according to standards and competency. The process to be able to have a common understanding of what would be achieved as well as manage your employees opportunities to achieve the greater goal is the responsibility of line management (Line Manager). Line managers are the employees who are authorized to organize one or more employees to achieve certain goals. In this study is meant by the line manager, every employee is given the responsibility to lead a unit that has one or more employees. Each definitions above, it can be concluded that line managers have a responsibility and a great influence on the effectiveness of the organization's work.

\section{Theoretical Framework}

a. Leadership toward the job effectiveness of employees

Thomas (2012) states, there are many theories that try to define leadership and clarify the role of leader. Most of this theory suggest increasing one's ability to lead. However, leaders must strive to take from all these theories and can't rely on just one theory. Leaders need to broaden their perspective on leadership continuously. Leaders need to develop their knowledge of leadership and improve the skills of employees to achieve the goal. In connection with this work is the need to place more emphasis on the importance of the relationship of the individual to the group's perspective, as a way to help empower individuals to excel in their work. The opinion was strengthened by Hersey and Blanchard (1988) to develop a model that identifies the Situational leadership style appropriate in a given situation depends on the model of the diagnosis of "readiness" of followers to perform the task. This model works on the premise that leaders can adjust their leadership styles to meet the demands of their environment. Leaders who can adapt to the environment will lead to results that effective employees or effectiveness of employees, if the employees at the level of mananerial will become an effective manager. This opinion is in line with Dalluay and Jalagat (2016), the results of his studies found a positive effect of leadership on the performance of an effective manager.

Furthermore Thawabieh and Dalluay (2016) stated Leadership refers to people who have the visionary mindset and can be able to lead and influence others to become leaders in attaining the goals and objectives of the business. From the view of Hersey and Blanchard (1988) and study results of Dalluay and 
Jalagat (2016), meaning that leaders with situational leadership style can be formed at the managerial level employees have an effective performance to achieve organizational success. Based on previous research, organizational effectiveness by Lance and Berger in Aswathappa (2015) Also Gibson (2012) As well as some research has been done by the Hay Group, Beriapeck and Harter (2014) That the variables of leadership (leadership) (X1) can be predicted directly Affect the effectiveness of employees (Y).

\section{b. Employee engagement toward the job effectiveness of employees}

According to Holbeche (2014), Employee Engagement is characterized by feelings of commitment, passion and energy which translates into a high degree of persistence, even with the most difficult task, exceeding expectations in taking the initiative. Also, Csikszentmihalyi (2014) state about "flow", which is the focus and psychologically happy so because so glad immersed in their jobs that they don't notice the passage of time. In a state of "flow", people are free to express "business freedom of action". From these two views of employees who have a certain degree of attachment, determines the magnitude of their role in the achievement of organizational goals. The greater the engagement of employees in the organization the more likely the achievement of organizational goals.

The survey conducted by Watson Wyatt Worldwide (Mone, et al. 2011) concluded that the company with a high level of attachment reaches 26 percent receipts (revenue) per employee is higher. Engagement help measures, including ensuring employees (1) understand how their departments contribute to the success of the company, (2) to understand how the business they do contribute to achieving the company's goals, and (3) have a sense of achievement while working at the company.

Employee engagement can be reflected as what happens in the workplace when people are interested and positive, even enthusiastic, about their work, ready to go the extra mile to be able to do the best of their ability by practicing "the tremendous effort" that is, to do more than which is normally expected of them, things that go beyond their job duties, and committed to the organization and the values they have. In other words, employees who have attachment to the organization will have an impact on the effectiveness of its performance. This view is supported by studies Sabado \& Welch (2012) who found the influence of engagement with the effectiveness of employee performance.

\section{c. Self-learning on the job effectiveness of employees}

The concept of self-regulation have been known for a long time, while the regulation of independent learning (learning self-regulation) is a more recent idea, which is an extension of the idea of self-regulation. Both concepts include motivation, purpose and systematic control over their core business. Both are active process that aims to achieve the goal. Both use of behavior management, assessment of the results to be obtained and adjust the action to be success and achieve goals. Both concepts describe the process of consultation, assessment and adaptive. Experienced employees can be developed effectively in the regulation of independent learning, while the new employee may still have a limited understanding of it.

Throughout employee goal-directed activity, great attention was paid to the skills / knowledge of what is needed to carry out the task, their experience related to the duties of an employee and the comfort level of the task (such as, expertise, talent and effort required). Thus the employee is an active learning and internalize the process of self-regulation for the purposes of themselves and adapt. Internalization regulation of independent learning can be enhanced through coaching.

The above description makes it clear that the concept of independent learning is closely related to autonomy and motivation which in turn will impact on the effective performance of employees. This means that in realizing the autonomy required independent learning motivation as a driver. Motivation does not just follow their own learning, but also includes an initiative to locate the material in order to support the learning process in question. The final goal of the study is that employees can master the job so that it can work more effectively and autonomy in their work, and want to share that lead to the effective performance of employees.

Self-learning has always been the basis for the development of organizational knowledge (collective). Using the term by Nonaka and Takeuchi (1995), externalization is the process tacid to explicit. Tacid Knowledge is born of self-study conducted by each individual, through the combination will generate knowledge organization. Internalized knowledge to individual organizations will further build organizational knowledge base, and so on. 


\section{d. Leadership toward self learning}

The existence of a new leadership paradigm presented by Bass (2000) reflected the Recipes Leadership in Learning Organizations. Meaning learning organization influenced by the style of leadership adopted by leaders. In line with these opinions, Senge (1990) states as a learning organization requires effective leadership. Learning organization is not only seen from multidiciplinary but also in terms of the level of organization and the individual level. At the organizational level, learning organization will be able to recognize their environment well so that it can defend itself in the middle of intense competition. At the individual level learning organization, will create an employee who is willing to learn on their own to achieve organizational goals.

According to Masanori (2017), Self-regulated learning is closely linked to the concept of autonomy, particularly subject in the aspects of metacognition, motivation, and learning behavior, which enable learners to take responsibility for review their own learning. From previous studies implied effect relationship between leadership and self-learning. Leadership style of directing someone to become independent learners.

\section{e. Employee Engagement toward Self Learning}

Matthew (2015), the Self-Regulated Learning process is at times described as a primarily metacognitive process, theorists also purpose that learners must process sufficient motivation to initiate and sustain reviews their engagement. The definition Self Learning has meaning when employees have an attachment to the organization, the employee had a great motivational become independent learners.

Independent learning is closely related to the concept of autonomy, especially in the aspects of metacognition, motivation, and learning behaviors, which enable learners to take responsibility for their own learning. Although the self-learning process is sometimes described as a major metacognitive process, theorists also intends that the students maintain enough motivation to start and maintain their attachment. When engaged in learning, strategies used learners and monitoring certainty that they make more influenced by the type and level of motivation they have. It is important to note that independent learning is understood as a process over and over. In the process of repetition of self-learning, motivation to influence behavior, and on the next repetition, motivation can be influenced by the past, the consequences of the behavior, or the results of the monitoring process. As a result, the motivation is understood as a dynamic component of the learning process independently varied during the learning takes place.

\section{f. Leadership toward Employee Engagement}

Hay's in Saul et al. (2015) captured the survey data from 330 companies from 50 countries that the perceptions and intentions of employees in the leadership were discovered, most employees leave their jobs because they were unhappy with their leaders. Furthermore Tims et al. in Saul et al. (2015) convey leadership style daily fluctuations may affect the self-belief of employees and employee engagement. The significance of the study results reinforce linkages leadership influence on employee engagement. A leader's style of leadership will affect employee motivation wholeheartedly carry out the work and participate fully in the work. However, there has not been much research that explores the relationship between the leadership of the degree of employee involvement, thus encouraging the study was conducted.

Research hypothesis

Based on the above, then the hypothesis is:

1. Leadership (X1) directly positive influence on the job effectiveness of employees (Y).

2. Employee engagement (X2) directly positive effect on the job effectiveness of employees (Y).

3. Independent learning (self-learning) (X3) directly positive effect on the job effectiveness of employees (Y).

4. Leadership (X1) directly positive effect on employee engagement (X2).

5. Leadership (X1) directly positive effect on self-regulated learning (self-learning) (X3).

6. Employee engagement (X2) directly positive effect on self-regulated learning (self-learning) (X3). 


\section{Research Methods}

Research carried out on employees of PT. Bank Tabungan Negara (Persero) Tbk branch employees to the position of line managers. This study used a survey method with quantitative approach, the instrument measuring instrument in the form of a questionnaire. Variable analysis consists of an endogenous variable (dependent) is the effectiveness of employees and exogenous (free) items, namely: leadership, employee engagement and independent learning. The test instrument carried out on 30 employees. The test result is a valid and reliable instrument grain instrument.

The instrument has been tested and then used as a research instrument. This study population as many as 133 employees of line managers in branch offices in Jakarta and surrounding areas, using the technique of saturated sampling.

Analysis was done by using descriptive and inferential statistics. Descriptive statistical techniques are used to describe the results of the study variables score. Inferential statistics by using path analysis is used to explain the influence of exogenous variables on endogenous variables.

\section{Finding, Results and Discussion The job effectiveness of employees}

Based on the data that is performed by using SPSS to variable performance effectiveness of employee presented in Table 4.1 below:

\section{Tabel 4. 1 Decriptive Statistic of job Effectiveness of Employee}

Table 4. 1 Data Statistics Employee Effectiveness

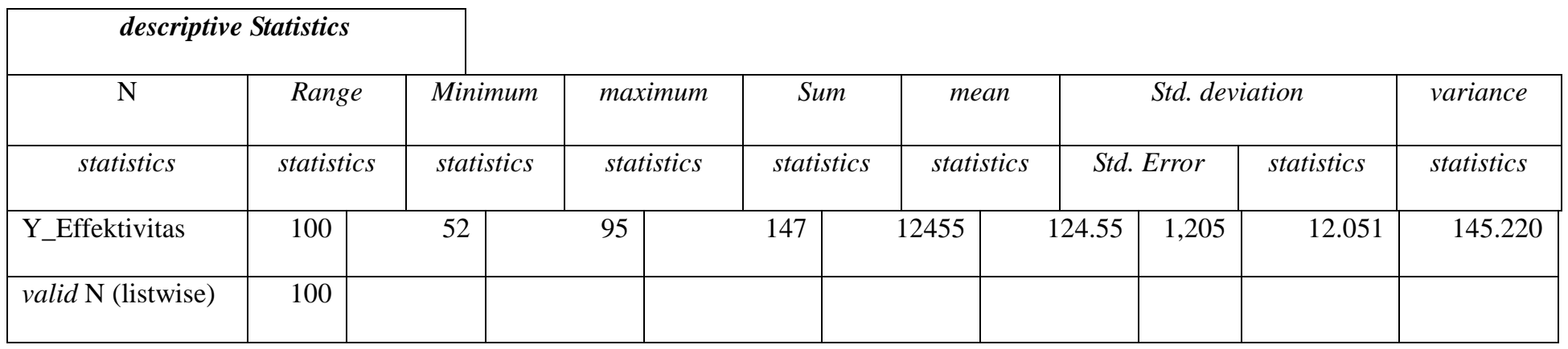

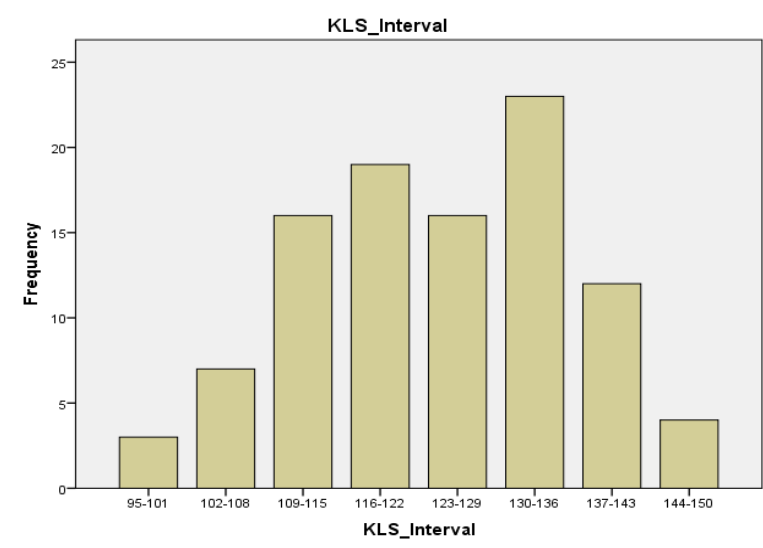

Source: Research Data management results in 2017.

Source: Research Findings 2017

Table 4.1 of the data generated by the study sample (n) of 100 respondents, with a minimum value of 95 and a maximum of 147 with an average (mean) of 124.55. Variance (variance) 145.22012 .051 and a standard deviation of length classes (range) of 52. 


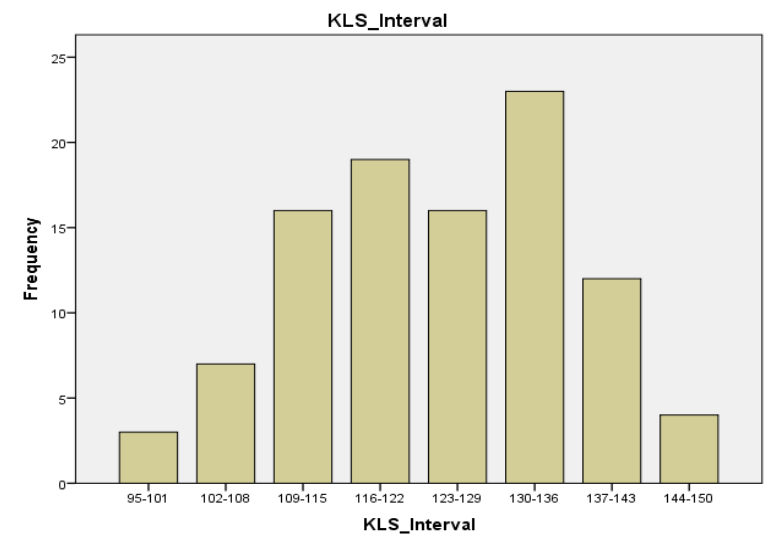

Source: Research Data management results in 2017

The data dissemination in the interval $130-136$ class is as much as $23 \%$. While the spread of the smallest in the class interval of 95-101 is only 3\%. Spreading the next smallest in the class interval 144-150 by $4 \%$. Overall spread of data in the below average cumulative grade interval there by $45 \%$. Being that there is above average, ratasebesar $39 \%$.

\section{Leadership}

Based on data management is done by using SPSS to variable data obtained Leadership as presented in the table 4.2 below:

Table 4. 2 Deccriptive Statistics Leadership

\begin{tabular}{|c|c|c|c|c|c|c|c|c|c|}
\hline & $\mathrm{N}$ & $\begin{array}{c}\text { Ran } \\
\text { ge }\end{array}$ & $\begin{array}{c}\text { Min } \\
\text { imu } \\
m\end{array}$ & \begin{tabular}{|c|} 
Max \\
imu \\
$m$
\end{tabular} & \multicolumn{2}{|c|}{ Sum } & mean & $\begin{array}{c}\text { Std. } \\
\text { deviatio } \\
n\end{array}$ & variance \\
\hline & $\begin{array}{l}\text { stati } \\
\text { stics }\end{array}$ & $\begin{array}{c}\text { stat } \\
\text { istic } \\
s\end{array}$ & $\begin{array}{l}\text { stati } \\
\text { stics }\end{array}$ & $\begin{array}{l}\text { stati } \\
\text { stics }\end{array}$ & $\begin{array}{c}\text { statis } \\
\text { tics }\end{array}$ & $\begin{array}{l}\text { stati } \\
\text { stics }\end{array}$ & $\begin{array}{c}\text { Std. } \\
\text { Error }\end{array}$ & $\begin{array}{c}\text { Statistic } \\
s\end{array}$ & statistics \\
\hline $\begin{array}{l}\text { X1_Kep } \\
\text { mimp }\end{array}$ & 100 & 55 & 105 & 160 & $\begin{array}{r}1324 \\
6\end{array}$ & $\begin{array}{r}132 . \\
46\end{array}$ & 1,507 & 15.065 & 226.958 \\
\hline $\begin{array}{l}\text { Valid N } \\
\text { (listwise } \\
\text { ) }\end{array}$ & 100 & & & & & & & & \\
\hline
\end{tabular}

Source: Research Findings 2017

Table 4.2 of the data generated by the study sample (n) of 100 respondents, with a minimum value of 105 and a maximum of 160, with an average (mean) of 132.46 Variance (variance) 226.958, the standard deviation of 15065 and the length of the class (range) at 55. 


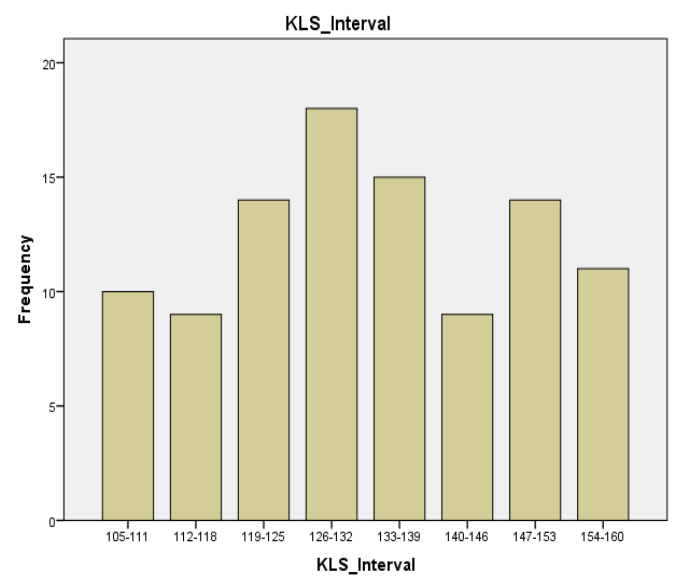

Source: Research Data management results in 2017.

The data dissemination in the interval 126-132 class as much as $18 \%$, while the spread of the smallest in the class interval 112-118 and 140-146 in the amount of 9\%. Overall spread of data in the below average cumulative grade interval there by $33 \%$. While that is above the average of $49 \%$.

\section{Employees Engagement}

Based on data management is done by using SPSS to variable attachment to employees obtained the data as presented in Table 4.3 below:

Table 4. 3 Statistics Employee Engagement

descriptive Statistics

\begin{tabular}{|c|c|c|c|c|c|c|c|c|c|c|}
\hline & $\mathrm{N}$ & $\begin{array}{c}\operatorname{Ran} \\
e\end{array}$ & $\begin{array}{l}M \\
m\end{array}$ & $\begin{array}{l}i n i \\
\text { im }\end{array}$ & $\begin{array}{l}\text { maxi } \\
\text { mum }\end{array}$ & Sum & mean & $\begin{array}{c}\text { Std. } \\
\text { devia } \\
\text { tion }\end{array}$ & & riance \\
\hline & $\begin{array}{l}\text { stati } \\
\text { stics }\end{array}$ & $\begin{array}{l}\text { sta } \\
t i s t \\
i c s\end{array}$ & $\begin{array}{c}\text { stat } \\
\text { istic } \\
\quad s\end{array}$ & $\begin{array}{l}\text { Stati } \\
\text { stics }\end{array}$ & $\begin{array}{c}\text { statis } \\
\text { tics }\end{array}$ & $\begin{array}{c}\text { statist } \\
\text { ics }\end{array}$ & $\begin{array}{c}\text { Std. } \\
\text { Error }\end{array}$ & \multicolumn{2}{|c|}{ statistics } & statistics \\
\hline $\begin{array}{l}\mathrm{X} 2 \_\mathrm{Ke} \\
\text { trikata } \\
\mathrm{n}\end{array}$ & 100 & 68 & 112 & 180 & $\begin{array}{r}16 \\
115\end{array}$ & $\begin{array}{r}161.1 \\
5\end{array}$ & 1,348 & 13. & & 237.136 \\
\hline $\begin{array}{l}\text { Valid N } \\
\text { (listwis } \\
\text { e) }\end{array}$ & 100 & & & & & & & & & \\
\hline
\end{tabular}

Source: Research Findings 2017

Table 4.3 is generated from data in the study sample (n) of 100 respondents, with a minimum value of 112 and a maximum of 180, with an average (mean) of 161.15. Variance (variance) 237.136, the standard deviation of 13475 and class length (range) of 68 . 
Graph 4.3. Employees Engagement Frequency

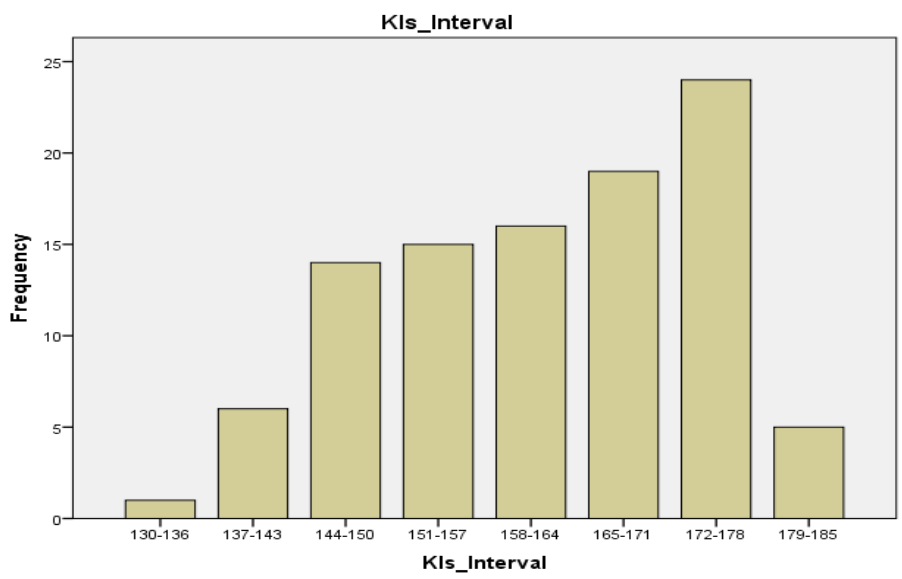

Source: Research Data management results in 2017.

The data dissemination in the interval 172-178 grade of 24\%. while the spread of the smallest in the class interval $130-136$ which is only $1 \%$. The next smallest deployment in the interval $179-185$ grade is $5 \%$.

\section{Independent learning}

Based on the data management menggu-nakan program Independent Learning SPSS to variable data obtained as presented in Table 4.7.

\section{Statistics Self- Learning Table 4.4}

\section{descriptive Statistics}

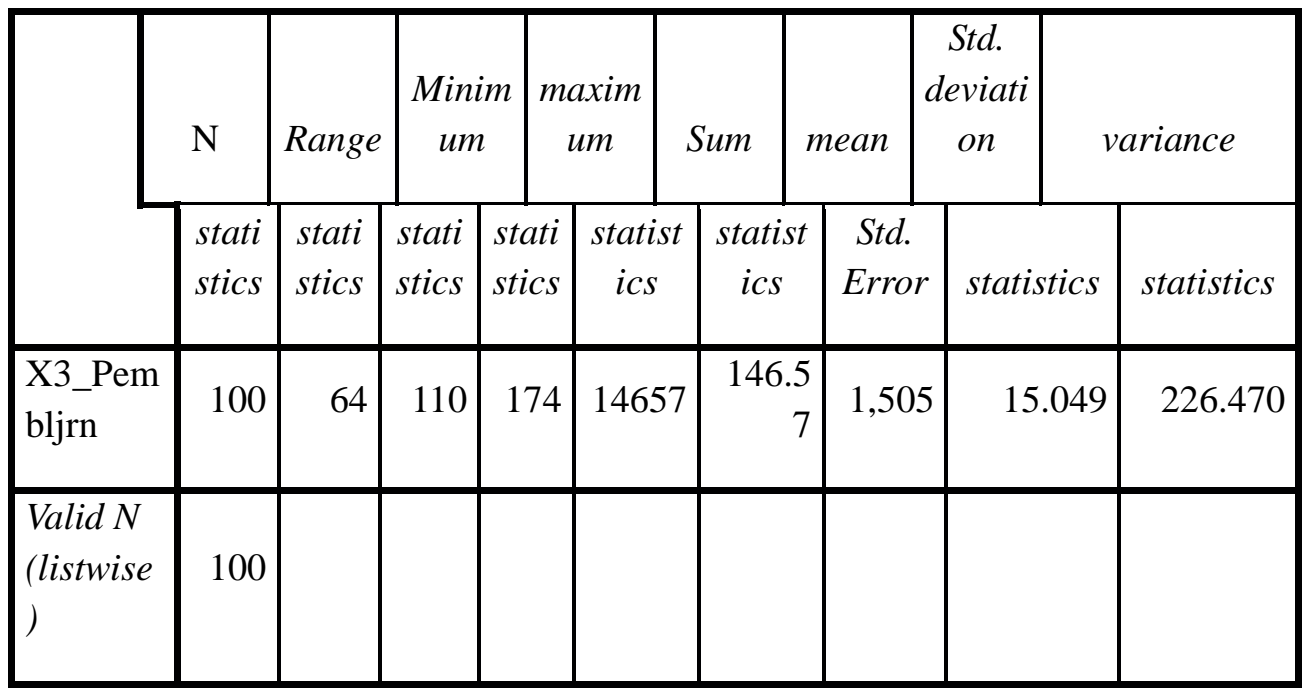

Table 4.4 of the data generated by the study sample (n) of 100 respondents, with a minimum value of 110 and a maximum of 174, with an average (mean) of 146.57, Variance (variance) 226.470, the standard deviation of 15049 and class length (range) of 64. 


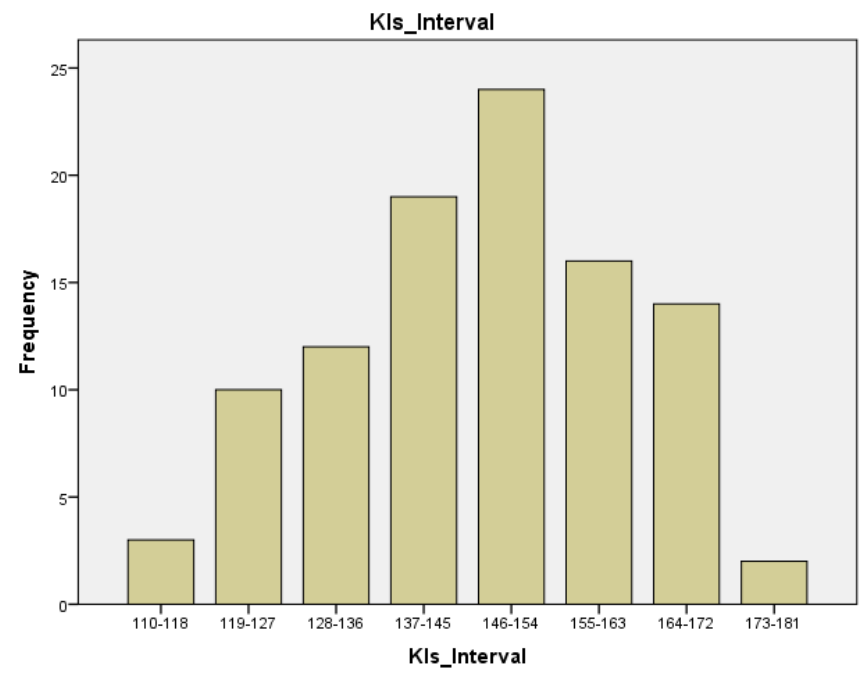

Source: Research Data management results in 2017.

The data dissemination in the interval 146-154 grade of 24\%. while the spread of the smallest in the class interval $173-181$ by $2 \%$, while the deployment of the next smallest in the interval 110-118 3\%. Overall spread of data in the below average cumulative grade interval there by $44 \%$. While that is above the average of $32 \%$.

Based on the results of inferential statistical analysis techniques Obtained pathway analysis linkages between variables and summary results of hypothesis testing as follows:

Picture 4.1: Complete Line Diagram Research Variables.

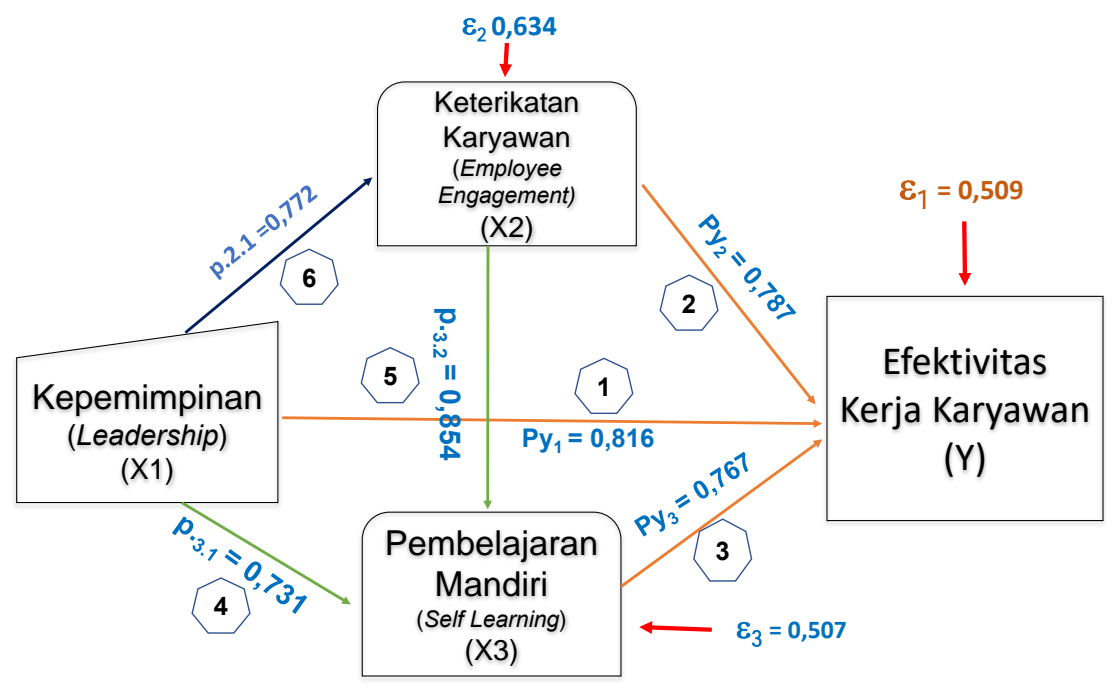

Gambar Model yang digunakan dalam penelitian. 
Table 4.5. The results of hypothesis testing is displayed in the below:

\begin{tabular}{|c|c|c|c|c|c|}
\hline No & Hypothesis & statistic test & $\begin{array}{c}\text { Line } \\
\text { coefficient }\end{array}$ & $\begin{array}{c}\text { Tcount } \\
*)\end{array}$ & decision \\
\hline 1. & $\begin{array}{l}\text { Leadership (X1) } \\
\text { has a directly } \\
\text { positive effect on } \\
\text { Efectivity } \\
\text { Employees (Y) }\end{array}$ & $\begin{array}{l}\mathrm{H} 0: \beta 1 \leq 0 \\
\mathrm{H} 1: \beta 1>0\end{array}$ & $\begin{array}{l}\text { Py1 } \\
0816 .\end{array}$ & 13985 & $\begin{array}{l}\mathrm{H} 0 \text { is rejected, } \\
\text { meaning that } \\
\text { the X1 driving } \\
\text { directly } \\
\text { positive effect } \\
\text { to }(\mathrm{Y})\end{array}$ \\
\hline 2. & $\begin{array}{l}\text { Employees } \\
\text { Engagement (X2) } \\
\text { directly positive } \\
\text { effect against the } \\
\text { Employee } \\
\text { Effectiveness (Y) }\end{array}$ & 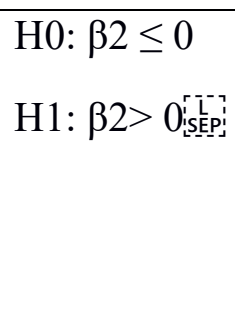 & $\begin{array}{l}\text { Py2 } \\
0787 .\end{array}$ & 12628 & $\begin{array}{l}\mathrm{H} 0 \text { is rejected, } \\
\text { meaning that } \\
\text { the } \mathrm{X} 2 \text { positive } \\
\text { effect directly } \\
\text { against }(\mathrm{Y})\end{array}$ \\
\hline 3. & $\begin{array}{l}\text { Independent } \\
\text { Learning (X3) } \\
\text { directly positive } \\
\text { effect on the } \\
\text { Employee } \\
\text { Effectiveness (Y) }\end{array}$ & $\begin{array}{l}\mathrm{H} 0: \beta 3 \leq 0 \\
\mathrm{H} 1: \beta 3>0 \text { : }\end{array}$ & $\begin{array}{l}\text { Py3 } \\
0.767\end{array}$ & 11817 & $\begin{array}{l}\mathrm{H} 0 \text { is rejected, } \\
\text { meaning that } \\
\mathrm{X} 3 \text { directly } \\
\text { positive effect } \\
\text { against }(\mathrm{Y})\end{array}$ \\
\hline 4. & $\begin{array}{lr}\text { Leadership } & \text { (X1) } \\
\text { directly positive } \\
\text { effect } \\
\text { employee } \\
\text { engagement (X2) }\end{array}$ & 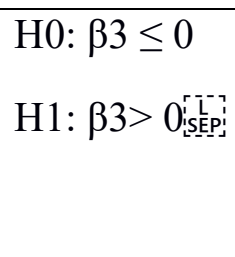 & $\begin{array}{l}\text { P2.1 } \\
0772\end{array}$ & 12038 & $\begin{array}{l}\mathrm{H} 0 \text { is rejected, } \\
\text { meaning that } \\
\text { directly effect } \\
\text { against positive } \\
\mathrm{X} 1(\mathrm{X} 2)\end{array}$ \\
\hline 5. & $\begin{array}{l}\text { Leadership (X1) } \\
\text { directly positive } \\
\text { effect on the } \\
\text { Independent } \\
\text { Learning (X3) }\end{array}$ & 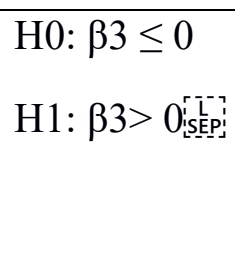 & $\begin{array}{l}\text { P3.1 } \\
0731\end{array}$ & 10609 & $\begin{array}{l}\text { H0 is rejected, } \\
\text { meaning that } \\
\text { directly effect } \\
\text { to the positive } \\
\mathrm{X} 1 \text { (X3) }\end{array}$ \\
\hline 6. & $\begin{array}{l}\text { Employees } \\
\text { Engagement (X2) } \\
\text { influenced } \\
\text { directly positive } \\
\text { effect on Self } \\
\text { Learning (X3) }\end{array}$ & $\begin{array}{l}\mathrm{H} 0: \beta 6 \leq 0 \\
\mathrm{H} 1: \beta 6>0 \text { 0 }\end{array}$ & $\begin{array}{l}\text { P3.2 } \\
0854\end{array}$ & 16242 & $\begin{array}{l}\text { H0 is rejected, } \\
\text { meaning that } \\
\text { positive } \mathrm{X} 2 \\
\text { directly } \\
\text { positive effect } \\
\text { on Self } \\
\text { Learning (X3) }\end{array}$ \\
\hline
\end{tabular}

\section{The Discussion of The Research Results}

\section{The leadership of the positive influences the effectiveness of the Employee}

The test results prove that the hypothesis that the leadership of the positive influence directly on the effectiveness of the employee. The leadership (Leadership) in this research is the use of power and influence to direct the activities of followers in the destination through increased ability or skills employees.

From the results of the questionnaire submitted to the respondents, seen that power usage patterns with directing method is still the main choice of respondents, followed by the method of coaching, 
then 3.Delegating and last method followed by the participating methods.

View of the implementation of the leadership style as conveyed by Hersey and Blanchard (1988), in the model of situational answer Leadership that detriment, identify that the right leadership style in a situation must depend on the model of the diagnosis of "readiness" followers to perform the tasks.

With the implementation of the dominant method of directing and coaching, illustrates that subordinate types that become the responsibility of respondents (adherents are those who dikategorokan on employees (followers) yet to rule with good job field (unable) and dominant also trouble with the behavior of the relationship (unwilling).

As noted by the Hersey and Blanchard that the approach in leading the influenced by two the behavior of the task behavior (task behavior), which sometimes called "instructions (directive)"; and the behavior of the relationship (relationship behavior). For followers who have not rule with good work then meode directing and coaching is the appropriate option in this case the desire to work from the followers of the low method directive more suitable.

The leadership is the ability or the skills of the leader in the form of : communication, praise, empowerment and training method for reproducing the skills of employees through the use of power and influence to direct the activities of followers and do with the people to achieve goals through other people.

To achieve that goal leaders influence or persuade others to prepare for behave differently with the use of power that includes : (1) organizational power that consists of (i) formal power; (ii) power awards; (iii) power coercive posturing; and (2) personal power which consist of (i) power experts; and (ii) power reference.

The power that belongs to the leader of the hypothesis test results have a positive effect on the effectiveness of the work of measured through 5 (five) dimensions, namely : (1) clarity of work target quantitative and qualitative research, (2) performance measurement (3) the ability of the employees (4) Monitoring performance (5) the evaluation of the implementation of the performance.

Based on the tabulation of the questionnaire that filled the respondents, from 100 respondents, as much as 80 respondents ( $80 \%$ ), fill the value of KPI (Key Performance Indictor) that he and his subordinates obtain top performance for the year 2016. On the data as much as $46(57 \%)$ respondents get very good assessment and Special, an assessment of the highest level that occurred in the Bank BTN, which shows the achievement of the performance $>100 \%$. (For very good values $>100 \% \mathrm{~s} / \mathrm{d}<110 \%$; for special value consecutive patients $110 \%$ ). According to the assessment can be concluded that based on the size of the assessment of the performance of the employees who have been working with effective.

Further study was done on a subordinate being supervised by the supervisor which become respondents obtained data, that $96 \%$ superiors who get special assessment and very good, produce inferior with the same performance.

Further study shows that from 46 respondents who get special assessment and very good as much as 27 respondents (59\%) more confidently in approach with the method directing 16 respondents (35\%) do the method of coaching and 3 respondents $(6 \%)$ with participating method.

Pay attention to the high approach by directing method (59\%) of employees from the side of the performance value is declared effective, shows that the approach purpose in stating the effectiveness of an employee is dominant. As according to Gibson that effectiveness in approach the purpose of is the achievement of business goals through cooperative basis. The idea that the organization, also as individuals and groups must be evaluated in terms of the achievement of the purpose of the broader meaning and practical. The achievement of business goals through cooperative basis is supported by the fact that $96 \%$ superiors who get special assessment and very good, produce inferior with the same performance.

The fact is in line with the framework of Organisational Effectiveness (Conceptual Model of Lance A. Berger Leadership mem-hikes affect the performance of the organization through engagement employees. Berger Model in line with the results of the path analysis, Leadership affects the effectiveness of the work of the employees of $66.6 \%$, enough influence singnifikan. The picture below is an image of the Organisational Effectiveness (Conceptual Model). 


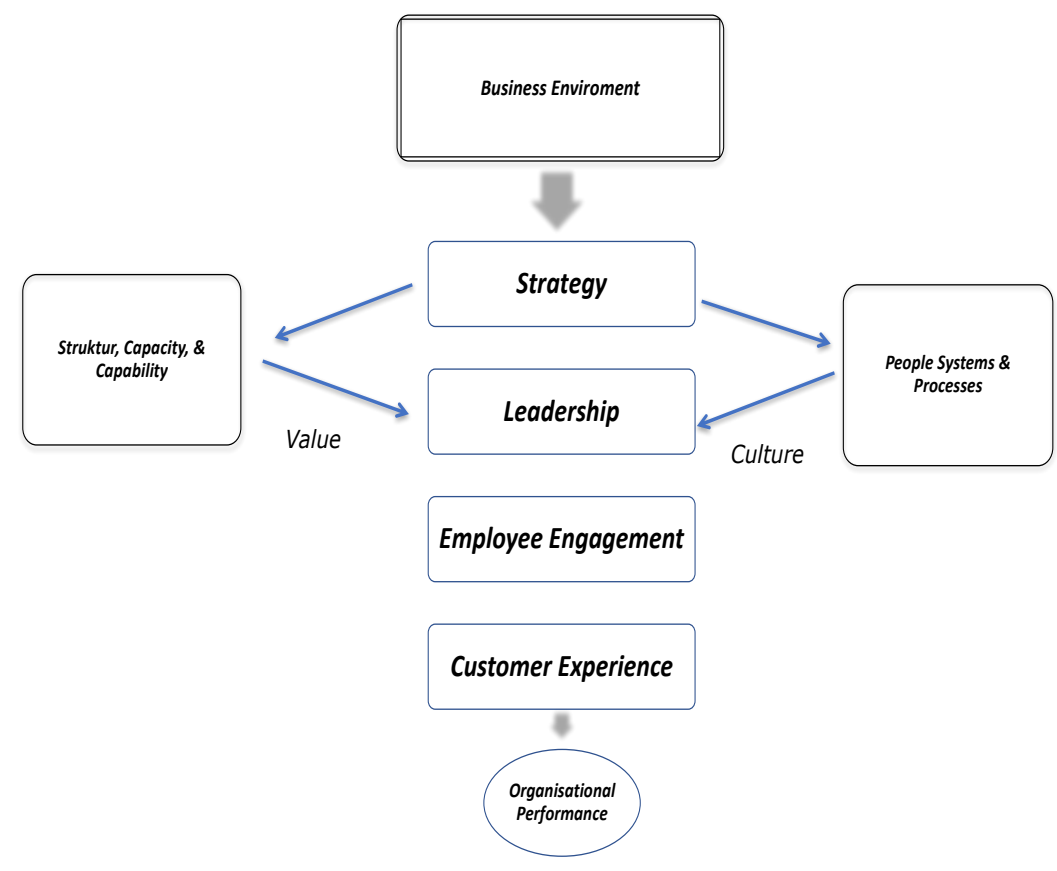

Based on investigations more deeply against the answers respondents, obtained the fact that the method 3.Delegating not as a dominant choice in the implementation of leadership style, refers to the theory of leadership model situational answer Leadership by Hersey and Blanchard, that leadership style is applied to the followers who have the ability to carry out the tasks at the same time have a high desire to carry out their duties. Thus the leader approach with Low relationship behaviour style and Low task behavior.

Based on the above facts, according to a researcher, coaching approach that has been applied (36\%) need to be enhanced intensity to improve the ability of the subordinate to able reserves (able) perform the task, thereby increasing the ability (ability), skills (skill), knowledge (knowledge) which is the determining factor for employees to achieve specified.

\section{Engagement employees have a positive effect on the effectiveness of the Employee}

The test results prove that the hypothesis that Employees engagement have positive influence directly on the effectiveness of the employee. Employees engagement in this research is the effort of free will encourage themselves to : (1) do a better job; (2) have positive feelings in work; (3) take an active role to discuss the subject of improvement of the work. And to convince others to : (1) understand how the department they have contributed to the success of the company; (2) understand how business that they do contribute to achieve the goal of the company; (3) have a sense of achievement. So that they are actively involved in decision making in the organization based on self-awareness.

From the results of the questionnaire submitted to the respondents, seen that the level of engagement of employees more dominant grow from mendorongan themselves. Respondents who get KPI special and very good, that categorized as employees is effective because they are able to reach the performance $>100 \%$. From 46 respondents (57 percent of respondents that inform the value of KPI) $71 \%$ more dominant encourage themselves in the braid engagement employees, only 3 percent of the employees who need the encouragement of the other side. This amount under the respondents who always plays an active, as many as $7 \%$. While the understanding of his role as much as 6 percent.

The most interesting part of respondents who get Istime assessment and very good this is, as much as 13 percent of respondents have a sense of achievement which often indicated. Thus can be categorized as a whole that the employees of high achievers in the Bank BTN has consciousness themselves to be effective there are as many as $97 \%$. Only 3 percent of respondents who strongly influenced by the other party to have engagement and become effective.

The height of the respondents with the performance of effective consciousness themselves to become effective taken the level of independence of the employees is high. This is in line with what is called 
Hughes with empowerment (empowerment) is process to reduce dependence employees to his superiors and give emphasis to the control of the individual on the responsibility for the work that must be done. The empowerment is one of the triggers from engagement employees.

The fact that 71 percent of employees who have the value of KPI is very good and special more dominant encourage themselves in the braid engagement employees prove that the empowerment of the employees walking significantly. This fact is in line with the opinion of the Royal and Agnew in employee effectiveness (framework, that the effectiveness of the employees affected by engagement employees covering commitment, business free efforts, Optimalization of Role and support the environment. The three factors namely commitment, business free efforts, optimization of the role of an effort that is based on the encouragement themselves.

A survey conducted by Gallup proved that employees with the extraordinarily high level have $83 \%$ chance with the performance on the average. Such is the case with Watson survey which concluded that the company with the level of the extraordinarily high, reached 26 percent acceptance (revenue) per employee is higher. Strong-Arm proposed there are nine actions that are agreed as the pusher engagement employees, and ninth among the actions that have the largest percentage is employees understand how the unit works to contribute to the success of the company. Self Awareness naturally born from nature individually.

The results of the analysis produced a band of $61.9 \%$ engagement employees affect the effectiveness of the employee. The number is quite significant and in line with the theory and the results of surevey as described previously.

\section{Self-learning positive influence the effectiveness of the Employee}

The results of the hypothesis testing proves that the Self learning positive influence directly on the effectiveness of the employee. Self learning (Self learning is learning which is done by itself without a teacher or instructor. In this research is a self learning is the process of digging the knowledge that was done by each individual on the initiative of the individual supported by the company with the aim to present social capital (social capital) so that created knowledge worker to increase competitiveness of the company, through 4 (four) learning steps: (i) mastery of knowledge (ii) Distribution Information (iii) the interpretation of information (iv) the remembrance of the organizational.

On the other hand the effectiveness of the employee can be achieved when the corresponding employees able to manage the ability (ability), skills (skill), knowledge (knowledge), behavior (attitude highly), motivation (motivation), stress (stress).

Excavations of the knowledge that was done by each individual directly affects knowledge (knowledge), capabilities (ability) and skills (skill), which required employees to work effectively. The three variables, is the determining variable effectiveness of individuals who first according to Gibson. (Ability ability), skills (skill and knowledge (knowledge), all three can be controlled by the individual when the learning process isself learning).

Based on the tabulation of the questionnaire that filled the respondents, from 100 respondents, as much as 80 respondents ( $80 \%$ ), fill the value of KPI (Key Performance Indictor) that he and his subordinates obtain top performance for the year 2016. On the data as much as $46(57 \%)$ respondents get very good assessment and special from that number, $44 \%$ has tended to apply as social capital and 32 percent act as Learning Organitation. Meanwhile 16\% employees behaving as Knowlegde walker. It Is about 8 percent more prone to Sharing Knowledge. While no employees who get the value of the KPI special and very good to behave dominant to teaching.

The choice of respondents dominant against the atmosphere of social capital, with itself becomes the basis for the creation of the commitment and creativity that is responsible for innovation, as was done by Gore in creating social capital, with how to :

A. Provide a working environment for easy to communicate.

B. Provide worker autonomy.

C. Just in the rewards.

In this case the company successfully presents social capital social capital) then will be created knowledge worker to increase competitiveness of the company, through 4 (four) learning steps: (i) the mastery of knowledge (ii) Distribution Information (iii) the interpretation of information (iv) the 
remembrance of the organizational. That is different from the results of the answers respondents is, for employees with the value of the KPI is very good and special no one dominant choose to do the lesson. This condition shows the tendency of learning more came into existence because of the interaction of the individual (personal) who created tacid become explicit knowledge.

The opinion of Nonaka (1995) in line with what is delivered Gore, that to create new knowledge very close relationship with sustainable interaction between tacid and explicit knowledge. Interaction certainly requires arana communication in a conducive environment.

The results of the analysis produced a band of 58.8\% self learning affect the effectiveness of the employee. This figure is underlying the conclusion Self learning positive influence directly on the effectiveness of the employee.

\section{The leadership (Leadership) positive effect toward Engagement Employees.}

The results of the hypothesis testing proves that the leadership of the positive influence directly against Engagement Employees. If seen the results of the calculation of the path coefficient, The Influence of Leadership against Engagement employees have the value of 59.6\%. This means that the leadership directly affects significantly against engagement employees.

As described in the previous section that is Leadership is the ability or the skills of the leader in the form of: communication, praise, empowerment and training to increase the skills of employees through the use of power and influence to direct the activities of followers and do with the people to achieve goals through other people.

While Engagement employees (Employee Engagement is the effort of free will encourage themselves to : (1) do a better job; (2) have positive feelings in work; (3) take an active role to discuss the subject of improvement of the work.

The leadership by the method of directing higher levels of its use as much as $59 \%$ even more stressed on high task behaviour and low relationship behavior, but provide a significant influence on engagement employees, according to researchers because level engagement employees more dominant influenced by the encouragement themselves (71\%), while engagement employees is realized because of encouragement from other parties not significant $(3 \%)$.

If gaze at on a theoretical model that is presented as quoted from Berger in Aswathappa (2015) On Picture 4.7 below:

\section{Organisational Effectiveness (Conceptual Model)}

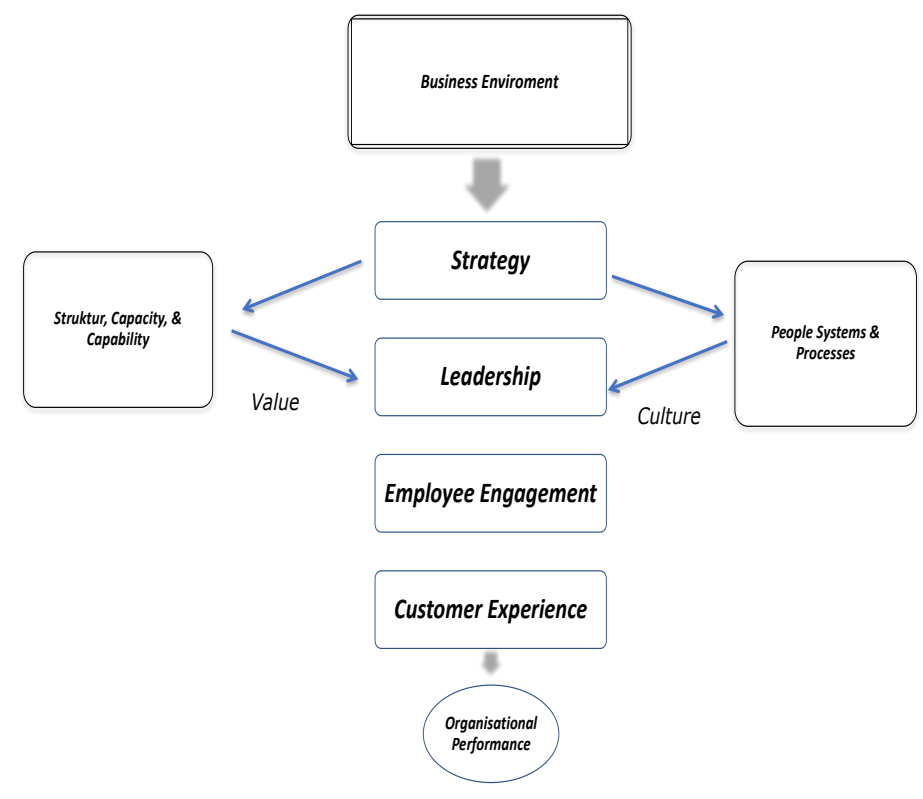


The Model Berger (2015) shows how the leadership of influence directly engagement employees and ultimately will affect the customer experience through the effectiveness of the employees who work in the end will affect the performance of the organization.

MacCleod and Clarke (2009) presents there are four things the pusher engagement employees, namely: Leadership that ensures the cultural organization that strong ; Manager who offers clarity; employees who feel they are capable of voicing their ideas and listening; confidence between employees that in the organization of life values and norms of prioritising observed and practiced.

Beck and Harter in Gallup (2014) reveals the research results published by Gallup (2014), that $82 \%$ of the companies failed in choosing the candidate talent management. Managers noted that there are at least 70 percent variance engagement employees in business unit. The impact is only 30 percent employees in America states that is tied to the workplace and to the level of the world there are only 13 percent of employees who have ties with the workplace.

The results of research that shows the line number 59.6\% influence engagement on the leadership of more small compared to the number of the path to the effectiveness of the employee over engagement employees namely $61.9 \%$ and the influence of the effectiveness of the employee on the leadership of $66.6 \%$, in line with the Conceptual Model of the Organisational Effectiveness (Conceptual Model that showed the influence of the leadership of engagement employees.

Based on the explanation above it can be concluded that the leadership of the positive influence directly against Engagement employees with the value of the path of 59.6\%.

\section{The leadership of the positive effect of Self learning}

The results of the test the hypothesis states that the leadership of surfing the positive influence directly against the self learning. As has been described in the previous section that in this research is a self learning is the process of digging the knowledge that was done by each individual on the initiative of the individual supported by the company with the aim to present social capital (social capital) so that created knowledge worker to increase competitiveness of the company, through 4 (four) learning steps: (i) the mastery of knowledge (ii) Distribution Information (iii) the interpretation of information (iv) the remembrance of the organizational.

While the Leadership in this research is the use of power and influence to direct the activities of followers in the destination through increased ability or skills employees. Leadership approach with the dominant pattern directing based on the condition of the follower is unable and unwilling, it means that the leader will need to improve and affect the independence of the employees to perform excavations toward improving knowledge that is supported by the company.

The influence of the leadership pattern according to researchers influenced by high task behavior which is used for individuals who are unable and un-willing to influence employees to hold the nature of the dominant, it needs to be created social capital. On the other hand, self learning choice dominant respondents against the atmosphere of social capital, with itself becomes the basis for the creation of the commitment and creativity that is responsible for innovation, means high task behavior in line used to individuals who have regional autonomy in work as well as that was created to deliver social capital.

The level of learning is not dominan option from respondents that have the value of KPI special and very good, to be separate issues for the leaders to use the pattern to the bringing of coaching to improve relationship behavior in the ka alter unwilling to become willing to grow as well as the independence.

Based on the value of the path, seen that the influence of the man-Learning themselves on the leadership of $53.4 \%$, thus seen clearly how the leadership of the positive effect is directly related to the dap Self learning.

\section{Employees Engagement have a positive effect on Self-learning}

Engagement employees in the Berger Model is the central that influence directly to experience customer that is the size of the organization performance. Apart from the leadership that affect engagement employees there is a culture and value. In culture there is a suite of system \& patterns in which including learning culture. Being in the value there is popularly, capacity and capability.

The opinion was in line with the Gibson that agglomerate factors that affect the effectiveness of the effectiveness of the individual is influenced by the ability (ability), skills (skill), knowledge 
(knowledge), behavior (attitude highly), motivation (motivation), stress (stress). While the effectiveness of the group influenced by kohesivitas (Cohesiveness), leadership (Leadership), the structure (Popularly), status (Status), the role (Roles) and norms (Norms). The cause of efektivitas organisatoris environment is (Environment), technology (Technology), the choice ofStrategic choices), structure (Popularly), the process (Patterns) and culture (Culture).

Armstrong (2009) see Employees engagement regarding the existence of elements of interest, positive attitude, eager, will their work, ready to work extra, exercising, is committed to the organization and the values that are destined. Practice and committed to the organization and the values that are destined, basically is part of self learning which is the process of digging the knowledge that was done by each individual on the initiative of the individual supported by the company with the aim to present social capital (social capital) so that created knowledge worker to increase competitiveness of the company.

Engagement employees (Employee Engagement defined in this research is the effort of free will encourage themselves to : (1) do a better job; (2) have positive feelings in work; (3) take an active role to discuss the subject of improvement of the work. And to convince others to : (1) understand how the department they have contributed to the success of the company; (2) understand how business that they do contribute to achieve the goal of the company; (3) have a sense of achievement. So that they are actively involved in decision making in the organization based on self-awareness.

Knowledge Worker as asserted by Peter according to Drucker (1991) is the human capital that is the experience and intelligence is far more important for the company compared with the skills of "physically" karyawanan or other capital of capital. Human Capital itself consists of various elements of competency among other capital, personality, psychology, motivation moral and emotional intelligence.

Engagement employees based on the results of the answers respondents shows that employees are bound more dominant caused by the encouragement ourselves, on the other hand self learning respondents more likely to deliver social capital. Social Capital as a basis to build commitment and creativity that is responsible for innovation, as applied by Gore.

The results of the hypothesis testing proves that Employees engagement have positive influence directly against the self learning. Based on the analysis of the path, influence path coefficient engagement employees with self learning is significant namely 0.729 or $72.9 \%$ is the value of the largest line koefficient.

\section{Conclusions and Recommendations}

The results of this study are: (1) Leadership has positive effect on Employee Effectiveness. This means that with the right leadership style may affect the effectiveness of employees. Directing leadership style (59\%) and coaching (36\%), applied to employees working Effectively. (2) Employee Engagement positively effect on Employee Effectiveness. The most dominant factors of employee engagement is to push yourself, it means that employees who have attachment and work Effectively acre Reviews those that have high levels of self dominant impulse. (3) Positive effect on the Independent Learning Employee Effectiveness. Employees who get very good ratings and special, do not show a dominant pattern Significantly, the tendency towards the realization of the social capital of $44 \%$. (4) Leadership positive effect on employee engagement. That is to show that leadership become key factors in employee engagement and simultaneously create organizational effectiveness. (5) Leadership positively effect on self-regulated learning. That is to show that social capital can be realized through the leadership that encourages the creation of a climate that allows for socialization and externalization to realize knowledge: tacid-tacid and tacid-explicit. (6) Employee Engagement is positively affects Self-Learning. That is to show that employees who have a high level of attachment is the employees who have the drive itself is dominant, so with social capital in independent learning, based on the Increase in the ability of employees on the basis of personal initiative. That is to show that social capital can be Realized through the leadership that encourages the creation of a climate that allows for socialization and externalization to realize knowledge: tacid-tacid and tacid-explicit. (6) Employee Engagement is positively affects Self-Learning. That is to show that employees who have a high level of attachment is the employees who have the drive itself is dominant, so with social capital in independent learning, based on the increase in the ability of employees on the basis of personal initiative.

Some of the Recommendations are: (1) PT. Bank Tabungan Negara (Persero) Tbk drafting periodic surveys to be able to identify the motivation and ability of employees in order to make it easier for line 
managers to implement a leadership style to improve the effectiveness of employees. (2) The design pattern needed of teaching (learning) leadership that managers were able to make adjustments to the pattern of leadership according to the situation faced by employees. (3) To improve the utilization of knowledge through self-study, companies need to create policies that provide rewards for employees who do the teaching or research that adds value to the company. (4) It should be made policies for employee education to impose a flexi-time to working hours, in order to allow employees to continue Reviews their education or to follow the lessons.

\section{References}

[1] Armstrong Michael. (2009). Armstrong's Handbook of Performance Management : An evidencebased guide to delivering high perfor-mance. London : Kogan Page, $4^{\text {th }}$ ed.

[2] Aswathappa, K. (2015). Human Resources Management: Text and Case, 7th ed., (New Dehli: McGraw Hill Education (India) privated Limited).

[3] Aswathappa, K. (2015). Human Resources Management: Text and Case. New Dehli: McGraw Hill Education (India) Privated Limited, $7^{\text {th }}$ ed.Bass, B. M. (2000). The future of leadership in learning organizations. Journal of leadership studies, 7(3), 18-40.

[4] Beck, Randall and Jim Harter. (2014) Why Great Managers Are So Rare, Gallup Business Journal.Source: http://www.gallup.com/businessjournal/ 167975 /why-great-managersrrare.aspx? g source $=$ Why $\% 20$ Great\%20 Managers \%20Are\%20so\%20rare\&g medium $=$ sear ch\&g_campaign=tiles accessed : $2^{\text {nd }}$ January 2017.

[5] Carasco-Saul, M., Kim, W., \& Kim, T. (2015). Leadership and employee engagement: Proposing research agendas through a review of literature. Human Resource Development Review, 14(1), 38-63.

[6] Csikszentmihalyi, Mihaly. (2014) Flow and the Foundations of Positive Psyc-hology: The Collected Works of Mihaly Csikszentmihalyi. Heidelberg: Springer.

[7] Drucker, Peter F. (1991). Management: Tasks, Responsibilities, Practices. Harper \& Row Publishers, Inc. New York

[8] Gibson, James L, et al. (2012). Organizations: Behavior, Structure, Processes. New York: McGrawHill Companies, Inc, $14^{\text {th }}$ ed.

[9] Griffin Griffin, Ricky W., Gregory Moorhead. (2014). Organizational Behavior: Managing People and Organizations. Mason: South-Western Cengage Learning, 11th edition. K. (201). Management of Organizational Behavior: Utilizing human resources, $5^{\text {th }}$ ed. (Englewood Cliffs, NJ: Prentice Hall International, 1988), h. 169. By Torrington, Derek, et al, Human Resources Management, $9^{\text {th }}$ ed., (Harlow: Pearson Education Limited), h. 220.

[11] Holbeche, Linda, Geo rey Matthews. (2012). Engaged: unleashing your organization's potential through employee engagement. San Francisco: John Wiley \& Sons.

[12] Masanori Yamada, et al. (2017). Learning analytics of the relationships among self-regulated learning, learning behaviors, and learning performance. Research and Practice in Technology Enhanced Learning, Vol. 12.

[13] MacLeod, D. and Clarke, N. (2009) Enggaging for Success: Enhancing Performance through Employee engagement. A report to Government. London: Department for Business, Innovation and Skills.

[14] Mattew L. Bernacki, Timothy J. Nokes-Malach. Vincent Aleven. (2015). Examinning self-efficacy during learning: variability and relations to behavior, performance, and learning. Metacognition and learning, Vol. 10 h. 100.

[15] Mone, E., Eisinger, C., Guggenheim, K., Price, B., \& Stine, C. (2011). Performance management at the wheel: Driving employee engagement in organizations. Journal of Business and Psychology, 26(2), 205-212.

[16] Nonaka, Ikujiro, and Takeuchi, H. (1995). The Knowledge Creating Company. New York: Oxford University Press.

[17] Sabado, A. V. G., \& Welch, J. (2012). Employee engagement: Its effectiveness to the employees in the health sector. Eur. J. Bus. Manage, 4, 100-107. 
[18] Senge, P. M. (1991). The fifth discipline, the art and practice of the learning organization. Performance + Instruction, 30(5), 37-37.

[19] Shikha N. K. (2010). Human resource practices and their impact on employee productivity: A Perceptual analysis of private, public and foreign bank employees in India. DSM Business Review, 2 (1).

Djiwandono. (2016) Looking back at the closure of 16 banks. Source: http: //www.pacific.net.id/ Expert / sj / sekitar_penutupan_16bank.

Thawabieh, F. A., Jalagat Jr, R. C., \& Dalluay, V. S. (2016). Impacts of Conflict Style Management of Selected Managers on Small-Size Businesses in United Arab Emirates. Business, Management and Economics Research, 2(9), 164-169.

[22] Thomas, Cornell. (2012). A call for engaged leadership. Rotterdam: Sense Publisher. https://www.deepdyve.com/lp/springer-journals accessed by: $7^{\text {th }}$ February 2018.

[23] Wolf, Jeff. (2015). Seven disciplines of a leader: How to help your people, team and organization Achieve maximum effectiveness. New Jersey: John Wiley \& Sons. https://www.deepdyve.com/lp/springer-journals. Accessed by: $7^{\text {th }}$ February 2018.

[24] http://www.btn.co.id/BTN 5IAP Menjadi Pemain Utama Program Sejuta Rumah, Laporan Tahunan 2015, PT. Bank Tabungan Negara (Persero) Tbk.

[25] http://www.ciputraentrepreneurship.com/amankan-bisnis/melihat-kembali-penyebab-kebangkrutanlehman-brothers-holdings accessed on $10^{\text {th }}$ February 2016.

[26] http://www.ciputraentrepreneurship.com/amankan-bisnis/melihat-kembali-penyebab-kebangkrutanlehman-brothers-holdings accessed on $10^{\text {th }}$ February 2016.

[27] http://thebusinessnews.co/2014/07/18/btn-lolos-pengawasan-intensif-tujuh-bank-segera-merger/ accessed on $19^{\text {th }}$ March 2016. 